\title{
Banking operations development in the context of stable interbank competition
}

\author{
Gulmira Nasyrova ${ }^{1}$, Larisa Yuzvovich $^{2 *}$, Elena Knyazeva $^{2}$, and Natalia Isakova $^{2}$ \\ ${ }^{1}$ L.N. Eurasian National University Gumilyov, 010008, st. Satpayev, 2 Astana, Kazakhstan \\ ${ }^{2}$ Ural State University of Economics, 8 Marta/Narodnoy Voli St. 62/45, 620144 Ekaterinburg, Russia
}

\begin{abstract}
A stable banking sector is important for any economy due to its colossal impact on both economic processes in the country and the life of society as a whole. Among the significant trends in the development of the banking sector for 2020, experts highlighted a significant reduction in the number of banks, an increase in the concentration of assets in the sector, the acquisition of IT companies by large banks and a reduction in the time spent on developing and launching new products, the development of biometrics and gamification of loyalty programs, strengthening of positions the largest credit institutions and an increase in the share of banks with government support. Let us emphasize that modern banks are entering the field of competition with large technological and financialtechnological corporations. They are forced to increase the availability, mobility, convenience and speed of service provision, to optimize costs by transforming the branch network, developing remote channels and analytics in terms of consumer preferences, which allows them to offer customers the most customized set of services. The subject of the research is the economic relations arising in the process of organizing banking operations in the context of interbank competition.
\end{abstract}

\section{Introduction}

According to the majority of experts, the Russian banking sector, which has been changing for several years, is still in the process of transformation. The changes concern not only the characteristics of banking products and services, which is an objective development of the market as a result of the introduction of modern information technologies in the financial sector, but also the regulation of banking activities and the structure of the banking market itself.

Thinking about the "stressful" scenarios caused by the fall in oil prices and the coronavirus epidemic, experts predict three scenarios - a crisis scenario - banks will have to create additional reserves, while the total volume of risk-weighted assets will decrease, negative - will also require additional reserves, but to a lesser extent, and banks in 2021 will show pre-tax profit and a moderate scenario will require significant efforts to maintain the quality of portfolios, but will not lead to losses [8].

${ }^{*}$ Corresponding author: yuzvovich@bk.ru 
It should be noted that, taking into account these trends and scenarios, the organic growth of the banking sector is reduced to a minimum. In the foreseeable future, only inorganic growth is possible due to mergers and acquisitions of smaller players in the banking market, including those who have not revised their business processes and values in favor of a customer orientation bathroom [10], since one of the most important trends in the banking sector, which has not lost its significance in a pandemic, it is a fight for the client. Consequently, the need is actualized not only for the analysis of the financial performance of the bank, but also for assessing its competitive position and identifying competitive advantages.

The variety and significance of the theoretical and practical aspects of interbank competition, including in terms of organizing and improving banking operations, require deepening fundamental and applied research on the formation of the necessary monetary resources that ensure competition in the banking sector in general and in particular in a particular commercial bank. This is quite relevant, since the policy of the banking sector of the economy has come to the fore among most subjects of economic relations, in this regard, the topic of scientific research devoted to the development of an adaptive methodology for assessing the integral indicator of a bank's competitiveness is relevant and has great practical importance, both for the national banking system. and for a separate commercial bank.

\section{Methodological approach to assessing banking competition}

In the context of the digital economy, the introduction of information technology is becoming one of the most important factors affecting the development of all sectors of the economy. The impact of this factor on competition in the banking sector is manifested, first of all, in the impact on the characteristics of banking services, as A. Krivoshchekin rightly notes "digitalization fundamentally changes the landscape of the banking sector. with the help of digital technologies, banks can customize services for the individual needs of each specific client, moreover, they can serve as providers of a wide range of services, including non-financial ones, in the "one window" mode" [5]. Banking competition, in contrast to the classical definition, according to many researchers, the concept is rather arbitrary, since not only banks compete in the banking market $[11,12]$.

Theoretical and empirical research in this area, we emphasize that banking competition is a debatable issue among economists and a rather complex phenomenon of modern economics. The classification of types of banking competition is presented in Table 1 .

Table 1. Classification of types of banking competition [7]

\begin{tabular}{|l|l|}
\hline \multicolumn{1}{|c|}{ Classification attribute } & \multicolumn{1}{c|}{ Type of banking competition } \\
\hline By type of economic activity & Intra-industry; intersectoral \\
\hline By category of participants & $\begin{array}{l}\text { Interbank; Between banks and non-bank } \\
\text { financial institutions }\end{array}$ \\
\hline $\begin{array}{l}\text { Depending on the market entities involved in } \\
\text { banking competition }\end{array}$ & $\begin{array}{l}\text { Competition between banking sellers; } \\
\text { competition between service buyers }\end{array}$ \\
\hline $\begin{array}{l}\text { Depending on the degree of concentration of } \\
\text { the subjects of banking competition }\end{array}$ & Individual competition; group competition \\
\hline $\begin{array}{l}\text { By subjects of competition of the federal and } \\
\text { regional markets }\end{array}$ & $\begin{array}{l}\text { Federal banks and their branches; regional } \\
\text { banks; banks with foreign capital }\end{array}$ \\
\hline $\begin{array}{l}\text { Depending on the methods of banking } \\
\text { competition used }\end{array}$ & Pricing; non-price \\
\hline $\begin{array}{l}\text { Depending on the degree of market } \\
\text { monopolization }\end{array}$ & Perfect; imperfect \\
\hline
\end{tabular}


Financial marketers develop products and services, attraction programs targeted at Generation X, Baby Boomers, Millennials. Empirical evidence suggests that "More than $80 \%$ of millennials cite rates and fees as the most important factors in choosing a bank. More than half of this generation is confident that their bank is no different from a competitor's bank located on the same street. A third of generations are ready to change banks within the next 90 days [3]. " $12 \%$ of the baby boomer generation is eager to share their negative experiences with banks at the earliest opportunity. $71 \%$ of baby boomers use an online bank at least once a week, $40 \%$ will not hesitate to go to another bank if the site of the current one is not convenient enough for them" [4].

The definition of the competitiveness of banking services in this regard needs to be clarified in terms of the characteristics of consumers, the rejection of the definition of "specific need" and strengthening of marketing orientation. We believe that the determinant of such an orientation should be relationship marketing, the key characteristics of which, according to Dwyer R. and Shurr H., are - the tendency to retain customers, constant relationships with the client, focus on his (client's) value, significant emphasis on service, attention to customer expectations and long-term planning. It is no coincidence that Vargo S. and Lush R. emphasize that the concept of service-oriented marketing is the development of such relationships with consumers, through which they become co-participants in the creation of customized, sustainable value propositions to meet their own specific needs.

Value orientation corresponds to modern concepts of economic and managerial knowledge (behavioral economics, cognitive marketing, "one-to-one" approach) and trends in the development of the banking sector. Orientation to value concepts prompts us to turn to generational theories (Howe N. and Strauss V., Radaeva V.V., Popova N.P., Pishchik V.I., etc.) according to most of which, generations largely determine values (values) of people. Let us emphasize that the type of generation certainly affects the expectations of consumers from banking products and services and the overall level of loyalty to banks.

The foregoing allows, in our opinion, to clarify the definition of the competitiveness of banking services as a sustainable value proposition in the field of money circulation and credit, ensuring the satisfaction of the complex needs of customers, and for retail banking services, value proposition taking into account the generational approach.

Researchers distinguish in its field, the so-called client approach, within which banking service is understood as the result of operations and customer service aimed at meeting their needs. Zelensky Yu.B. interprets banking service as the activity of banks and other credit institutions, which have been granted the right to conduct banking operations, carried out on behalf of and in the interests of their clients and aimed at meeting their needs. A banking operation as a complex of interrelated actions (transactions) performed by banks and other credit institutions, which are granted the exclusive right to carry them out by the current legislation [1]. Note that the concept of this researcher in the interpretation of banking operations is largely based on the legislative framework.

We believe that the integral methodology can be based on a balanced scorecard, including metrics for assessing financial stability and other assessment practices developed and used in the Russian banking sector. This will make it possible to level the limitations inherent in quantitative assessment metrics and subjectivity and one-dimensionality of qualitative instruments.

The purpose of the proposed methodology is a comparative analysis of the bank and competitors based on a combination of financial and non-financial data.

The tasks solved by this technique:

- identification of problem areas in the bank's activities;

- determination of internal and external competitive advantages of a credit institution;

- determination of the current competitive position of the bank. 
We emphasize that the choice of assessment tools and performance indicators depends on the current state of a particular bank, its strategic guidelines and the level of development of both the economy as a whole and the specific region of presence.

\section{Analysis of the competitiveness of banks and banking services}

It is noteworthy in this regard how expert assessments have changed on the development trends of the banking industry in 2020 in connection with the coronavirus pandemic and the economic downturn. Thus, the market leaders argued that "banks are preparing in 2020 to fight for the growth of mortgage and retail loans, and will continue to develop remote channels. They expect an increase in interest in savings accounts and individual investment accounts, as well as in the marketplace of financial products" [2, 9]. Let us present the forecasts of specialists in the pre- and crisis period in Table 2.

Table 2. Forecasts of experts on banking trends in the pre- and crisis period

\begin{tabular}{|c|c|}
\hline Banking trends of 2020 & Banking trends in the crisis and post-crisis period \\
\hline $\begin{array}{l}\text { Shifting competition from price to quality of } \\
\text { service, ease of interaction and communication } \\
\text { channels, opportunities for personalization and } \\
\text { design of products }\end{array}$ & $\begin{array}{l}\text { Development of remote services, digital channels, } \\
\text { creation of new products and offers that meet the } \\
\text { changing needs of customers, maintaining speed and } \\
\text { flexibility }\end{array}$ \\
\hline Growth in the number of investors - individuals & Closing of deposit accounts by Russian depositors \\
\hline Transfer of mortgage loans to online format & $\begin{array}{l}\text { Mortgage demand will start to recover in 18-24 months, } \\
\text { helping clients and stimulating lending }\end{array}$ \\
\hline $\begin{array}{l}\text { Development of non-banking services for } \\
\text { business }\end{array}$ & $\begin{array}{l}\text { Acquisition of technologies from European startups and } \\
\text { scaling them at home }\end{array}$ \\
\hline Optimization of banking networks & $\begin{array}{l}\text { revision of expenses and income, re-profiling of bank } \\
\text { branches }\end{array}$ \\
\hline Slowdown in retail lending growth & Non-return of credit funds \\
\hline Business lending growth & $\begin{array}{l}\text { Deterioration in the quality of the loan portfolio, } \\
\text { slowdown in lending, loan defaults by businesses }\end{array}$ \\
\hline Development of biometrics & \\
\hline Loyalty programs gamification & \\
\hline Diffusion of paperless technology & $\begin{array}{l}\text { Strengthening cooperation with IT companies, the use of } \\
\text { artificial intelligence }\end{array}$ \\
\hline Continued rate cuts & Key rate cut by the regulator \\
\hline
\end{tabular}

Table 2. Continued 


\begin{tabular}{|l|l|}
\hline Entering the fast payment system to a new level & \\
\hline $\begin{array}{l}\text { Decrease in the number of banks, the emergence } \\
\text { of new partnerships and alliances }\end{array}$ & $\begin{array}{l}\text { Reduction of the number of banks, decrease in } \\
\text { profitability, depreciation of portfolios of securities and } \\
\text { assets, growth of high-risk assets, search for } \\
\text { opportunities for new transactions, strengthening of the } \\
\text { quality of risk management }\end{array}$ \\
\hline
\end{tabular}

Understanding the fair caution of the forecasted estimates of specialists, due, inter alia, to the economic nature of the crisis, we cannot but state the fact that representatives of the expert community, both Russian and foreign, agree on the preservation and strengthening of a number of trends in the development of banking services announced in the pre-crisis period. , namely:

- creation of new services and products that are maximally focused on customer needs. Let us emphasize that we are talking not only about existing needs, but also about those that will arise due to new market conditions;

- maintaining and strengthening the trend for digitalization, analytical work with big data;

- maintaining the flexibility and quality of both service and business processes.

We believe that taking into account these trends, which, in fact, have become the mainstream of the banking sector, should be reflected in the metrics for assessing the competitiveness of banks and banking services. Using the tools and results of the SWOT analysis, the authors have developed a program to realize opportunities and prevent threats. Table 3 contains recommended measures to improve the efficiency of the functioning of a commercial bank, starting from the factors of influence of the internal and external environment.

Table 3. A set of measures to improve the efficiency of the functioning of a commercial bank based on SWOT analysis

\begin{tabular}{|c|c|c|c|c|c|c|c|}
\hline \multirow{2}{*}{$\begin{array}{l}\text { Categories } \\
\text { events }\end{array}$} & \multirow[t]{2}{*}{ of } & \multicolumn{3}{|c|}{ Strengths } & \multicolumn{3}{|c|}{ Weak sides } \\
\hline & & 1 & 2 & 3 & 1 & 2 & 3 \\
\hline \multirow[t]{3}{*}{ Opportunities } & 1 & \multicolumn{2}{|c|}{$\begin{array}{l}\text { Loyalty programs } \\
\text { gamification }\end{array}$} & $\begin{array}{l}\text { Virtualization of } \\
\text { interaction with } \\
\text { consumers of } \\
\text { generations } Y, Z\end{array}$ & \multicolumn{3}{|c|}{ Benchmarking application } \\
\hline & 2 & \multirow{2}{*}{\multicolumn{3}{|c|}{$\begin{array}{l}\text { Product offering in line with regional } \\
\text { consumer values }\end{array}$}} & \multicolumn{2}{|c|}{$\begin{array}{l}\text { Analysis of } \\
\text { business } \\
\text { processes from } \\
\text { the standpoint of } \\
\text { lean } \\
\text { manufacturing }\end{array}$} & $\begin{array}{c}\text { Customer } \\
\text { retention program } \\
\text { development }\end{array}$ \\
\hline & 3 & & & & \multicolumn{3}{|c|}{$\begin{array}{l}\text { Developing an internal marketing } \\
\text { strategy focused on increasing } \\
\text { employee satisfaction }\end{array}$} \\
\hline \multirow[t]{3}{*}{ Dangers } & 1 & \multirow{2}{*}{\multicolumn{2}{|c|}{$\begin{array}{c}\text { Branch network } \\
\text { optimization }\end{array}$}} & Working with & \multirow{2}{*}{\multicolumn{2}{|c|}{$\begin{array}{l}\text { Strengthening risk } \\
\text { management }\end{array}$}} & Strengthening \\
\hline & 2 & & & $\begin{array}{l}\text { behavioral attitudes } \\
\text { of the population }\end{array}$ & & & $\begin{array}{l}\text { customer- } \\
\text { centricity }\end{array}$ \\
\hline & 3 & \multicolumn{2}{|c|}{$\begin{array}{l}\text { Consumer } \\
\text { Preference } \\
\text { Research }\end{array}$} & $\begin{array}{l}\text { Creation of a product } \\
\text { focused on the } \\
\text { specifics of the values } \\
\text { of generations } Y, Z\end{array}$ & \multicolumn{2}{|c|}{$\begin{array}{l}\text { Development of } \\
\text { an up-to-date } \\
\text { corporate strategy }\end{array}$} & Specialization \\
\hline
\end{tabular}

Let's calculate the total value of the indicators for determining the priority of the activities, combined in the summary table 4 . 
Table 4. Priority SWOT analysis activities based on the calculated cumulative value

\begin{tabular}{|l|c|}
\hline \multicolumn{1}{|c|}{ Arrangement } & $\begin{array}{c}\text { The total value of } \\
\text { indicators }\end{array}$ \\
\hline Product offering in line with regional consumer values & 8,32 \\
\hline Branch network optimization & 8,04 \\
\hline Strengthening risk management & 5,44 \\
\hline $\begin{array}{l}\text { Developing an internal marketing strategy focused on increasing } \\
\text { employee satisfaction }\end{array}$ & 4.8 \\
\hline Consumer Preference Research & 3,6 \\
\hline Benchmarking application & 3,36 \\
\hline Development of an up-to-date corporate strategy & 3,2 \\
\hline Strengthening customer centricity & 2,72 \\
\hline Working with behavioral attitudes of the population & 2,72 \\
\hline Loyalty programs gamification & 2,52 \\
\hline $\begin{array}{l}\text { Analysis of business processes from the standpoint of "lean } \\
\text { manufacturing" }\end{array}$ & 1,92 \\
\hline $\begin{array}{l}\text { Creation of a product focused on the specifics of the values of } \\
\text { generations Y, Z }\end{array}$ & 1,6 \\
\hline Specialization & 1,6 \\
\hline Customer retention program development & 0,96 \\
\hline
\end{tabular}

Based on the results of the analysis, we can conclude that the most priority actions for the bank are activities related to the offer of banking services and products focused on the value system of regional consumers.

This methodology is focused on identifying "bottlenecks" in the areas of the bank's activities, obtaining an integral assessment (Table 5) and avoiding subjectivity in the assessment through the use of measurable indicators.

Table 5. Integral indicator of the competitiveness of the analyzed commercial bank

\begin{tabular}{|c|c|c|c|c|}
\hline $\begin{array}{c}\text { Activity } \\
\text { parameter }\end{array}$ & Assessment tool & $\begin{array}{l}\text { Performance } \\
\text { indicators }\end{array}$ & $\begin{array}{l}\text { Indicator } \\
\text { weight }\end{array}$ & $\begin{array}{c}\text { Parameter } \\
\text { weight }\end{array}$ \\
\hline \multirow[t]{2}{*}{ Financial } & CAMELS System & $\begin{array}{l}\text { Capital adequacy, } \\
60 \%\end{array}$ & 0,5 & \multirow[t]{2}{*}{0,25} \\
\hline & Cromonoff's method & $\begin{array}{l}\text { Reliability factor, } \\
40 \%\end{array}$ & 0,5 & \\
\hline \multirow[t]{2}{*}{ Client } & $\begin{array}{l}\text { Analysis of } \\
\text { complaints }\end{array}$ & $\begin{array}{l}\text { Relative assessment } \\
\text { of the speed of } \\
\text { response, the quality } \\
\text { of elaboration of } \\
\text { customer questions, } \\
70 \%\end{array}$ & 0,5 & \multirow[t]{2}{*}{0,25} \\
\hline & Reputation audit & $\begin{array}{l}\text { Relative assessment of } \\
\text { the information field of } \\
\text { the company, } 30 \%\end{array}$ & 0,5 & \\
\hline
\end{tabular}

Table 5. Continued

\begin{tabular}{|c|l|l|l|l|}
\hline Business & SWOT & Relative assessment & 0,5 & 0,25 \\
\hline
\end{tabular}




\begin{tabular}{|c|c|c|c|c|}
\hline \multirow[t]{2}{*}{ processes } & & $\begin{array}{l}\text { of the strengths and } \\
\text { weaknesses of the } \\
\text { bank in relation to the } \\
\text { opportunities and } \\
\text { threats of the external } \\
\text { environment, } 60 \%\end{array}$ & & \\
\hline & $\begin{array}{l}\text { Competitiveness } \\
\text { Assessment Sheet }\end{array}$ & $\begin{array}{l}\text { Relative assessment } \\
\text { of the bank's } \\
\text { marketing mix, } 40 \%\end{array}$ & 0,5 & \\
\hline \multirow[t]{2}{*}{ Staff } & $\begin{array}{l}\text { Analysis of corporate } \\
\text { documents of the } \\
\text { company (code of } \\
\text { ethics, code of } \\
\text { business ethics for } \\
\text { employees, corporate } \\
\text { code, collective } \\
\text { agreement) }\end{array}$ & $\begin{array}{l}\text { Relative assessment } \\
\text { of the views of the } \\
\text { bank's management } \\
\text { about the management } \\
\text { process, } 50 \%\end{array}$ & 0,5 & \multirow[t]{2}{*}{0,25} \\
\hline & $\begin{array}{l}\text { Qualitative analysis of } \\
\text { established } \\
\text { management practices }\end{array}$ & $\begin{array}{l}\text { Relative assessment } \\
\text { of the most important } \\
\text { features of } \\
\text { management practice, } \\
50 \%\end{array}$ & 0,5 & \\
\hline
\end{tabular}

As follows from the calculations carried out according to the presented metric, the weakest areas are personnel and business processes. Let us present the quantitative results of the calculation: financial factor - $12.5 \%$; customer factor - $15 \%$; business processes $11.25 \%$; personnel $-11.875 \%$, with a cumulative integral assessment $-50.625 \%$. Thus, the results of analytical studies indicate the need to transform strategic management and improve the competitive strategy of the bank based on the joining of the vectors of modern banking: digitalization, optimization of the banking network and maximum focus on customer needs and personalization of interaction.

Based on the balanced scorecard model and taking into account the identified problem areas, we will construct a forecast block diagram of the bank's strategic development map (Table 6).

Table 6. Block diagram of the bank's strategic development map

\begin{tabular}{|l|l|l|l|}
\hline Factor & Strategic goal & \multicolumn{1}{|c|}{ Index } & \multicolumn{1}{c|}{ Strategic actions } \\
\hline Finance & $\begin{array}{l}\text { Increasing the } \\
\text { financial stability } \\
\text { of the bank }\end{array}$ & $\begin{array}{l}\text { Increasing the level of capital } \\
\text { adequacy; } \\
\text { Increase in the level of return on } \\
\text { assets; } \\
\text { Increase in the level of } \\
\text { investment activity }\end{array}$ & $\begin{array}{l}\text { Improving banking operations in } \\
\text { terms of working with } \\
\text { concentrated segments; Pilot } \\
\text { launch (within the framework of } \\
\text { the promotion) of the Freemium } \\
\text { business model for the millennial } \\
\text { segment }\end{array}$ \\
\hline Clients & Corporate business & $\begin{array}{l}\text { Maintaining positions in } \\
\text { investment banking services }\end{array}$ & $\begin{array}{l}\text { Increased commissions on } \\
\text { transactional products }\end{array}$ \\
\cline { 2 - 4 } & $\begin{array}{l}\text { Small and medium } \\
\text { businesses }\end{array}$ & $\begin{array}{l}\text { Increase in the number of } \\
\text { offered non-banking services }\end{array}$ & $\begin{array}{l}\text { Increasing the share of sales } \\
\text { through digital channels }\end{array}$ \\
\cline { 2 - 4 } & Retail & $\begin{array}{l}\text { Increasing the share of multi- } \\
\text { product customers }\end{array}$ & $\begin{array}{l}\text { Focus on the values and needs of } \\
\text { consumers in the region }\end{array}$ \\
\cline { 2 - 3 } & Increasing the customer base & \\
\hline Table 6. Continued & \multicolumn{2}{|l}{} \\
\hline
\end{tabular}




\begin{tabular}{|c|c|c|c|}
\hline \multirow[t]{4}{*}{$\begin{array}{l}\text { Business } \\
\text { processes }\end{array}$} & Banking products & $\begin{array}{l}\text { Product availability in remote } \\
\text { channels }\end{array}$ & \multirow{2}{*}{$\begin{array}{l}\text { Digitalization of channels of } \\
\text { interaction with customers, } \\
\text { increasing the speed of the bank's } \\
\text { response to changes in the market } \\
\text { and customer demand }\end{array}$} \\
\hline & & $\begin{array}{l}\text { Growth in the share of service } \\
\text { operations transferred to remote } \\
\text { channels }\end{array}$ & \\
\hline & Internal processes & $\begin{array}{l}\text { Migration of internal processes } \\
\text { to the IT landscape }\end{array}$ & $\begin{array}{l}\text { Transition to paperless internal } \\
\text { workflow }\end{array}$ \\
\hline & Branch network & Network optimization & $\begin{array}{l}\text { Closing duplicate branches in the } \\
\text { regions }\end{array}$ \\
\hline \multirow[t]{3}{*}{ Staff } & Corporate culture & $\begin{array}{l}\text { Bank employee commitment } \\
\text { index }\end{array}$ & \multirow{2}{*}{$\begin{array}{l}\text { Conducting a study of corporate } \\
\text { culture in order to identify } \\
\text { bottlenecks, conducting strategic } \\
\text { sessions to develop strategic } \\
\text { initiatives }\end{array}$} \\
\hline & & $\begin{array}{l}\text { Motivation and satisfaction } \\
\text { index }\end{array}$ & \\
\hline & Technology & $\begin{array}{l}\text { Number of digital technology } \\
\text { implementations }\end{array}$ & $\begin{array}{l}\text { Reorganization of business } \\
\text { processes }\end{array}$ \\
\hline
\end{tabular}

In our proposed predictive flowchart, development targets are deliberately not declared. We believe that the quantitative formalization of targets should be done after the partial lifting of quarantine measures due to an unfavorable epidemiological situation, based on the control measurements of the significant indicators proposed in Table 31. While part of the strategic actions can be taken for implementation in the current period. The proposed block diagram corresponds to the current trends in the development of the banking sector and is focused on maximizing the client-centricity of the studied bank. It is the construction of a real, and not a translated system of customer focus that can lead to obtaining the declared effects and strengthening the financial stability of the bank in the context of interbank competition.

\section{Acknowledgements}

As part of the research, we would like to express our gratitude to Irina Vasilievna Kotlyarevskaya - Doctor of Economics, Professor, Head of the Marketing Department of the Ural Federal University and Svetlana Nikolaevna Lapshina - Candidate of Technical Sciences, Associate Professor of the Department of Analysis and Decision Making Systems at the Ural Federal University for the SWOT analysis methodology provided.

\section{References}

1. N.P. Abaeva, L.T. Khasanova, Competitiveness of banking services, 118 (2012)

2. Banking Industry - 2020: Leaders' Forecasts, https://pro.rbc.ru/

3. How Millennials Will Change the Financial Services Market, https://arb.ru/b2b/

4. B. Kudryavtsev, T. Zhmereva, The older audience is no less interesting for banks than young people: expert comments, https://arb.ru/

5. A. Krivoshchekin, Digitalization fundamentally changes the landscape of the banking sector, https://plus.rbc.ru/

6. O.M. Tsuglenok, Epoch of Science, 21 (2020) 
7. I.A. Chekhovskaya, V.V. Yarova, Financial analytics: problems and solutions, 21 (303) (2016)

8. What banks should do after the COVID-19 pandemic: McKinsey advice, https://frankrg.com/

9. V. Shrinivas , J.-T. Shops, T. Ramsay, Banks 2020 - a time of change and innovation, https://www.finam.ru/

10. G.A. Akerlof, R.J. Shiller, Phishing for Phools: The Economics of Manipulation and Deception (2015)

11. L. Reznichenko, Y. Guseynova, Competitive positioning of commercial banks on the base of innovative banking services and technologies (2015)

12. O.V. Derevyanko, Assessment of competitiveness of commercial banks and method of detection competitors in the banking market (2016) 